Filip Cyuńczyk

ORCID: 0000-0003-2669-7822

Uniwersytet Wrocławski

\title{
Zmagania Europy Środkowej z pamięcią a koncepcje przyzwoitego społeczeństwa i etyki pamięci Avishaia Margalita
}

Abstrakt: Głównym zadaniem niniejszego tekstu jest identyfikacja i prezentacja potencjału kategorii filozoficznych Margalita dla środkowoeuropejskich badań nad rolą społecznych pamięci zbiorowych, a także w celu określenia znaczenia tych pamięci w procesach konstytuowania wspólnot politycznych po 1989 roku. Zarówno „przyzwoite społeczeństwo”, jak i „etyka pamięci” mogą stanowić wartość dodaną dotychczasowych rozważań na ten temat. Dlatego też zostaną one zestawione ze stanem badań nad prawną petryfikacją społecznych pamięci zbiorowych przez poszczególne środkowoeuropejskie czynniki polityczne. Podjęcie tych zagadnień pozwoli zidentyfikować obszary, które mogłyby zostać wzbogacone przez filozofię Margalita.

Słowa-klucze: polityka pamięci, konstytucjonalizacja, pamięć zbiorowa, przyzwoite społeczeństwo, etyka pamięci, przejście demokratyczne, Europa Środkowa i Wschodnia

Zarówno w publicznym, jak i w akademickim dyskursie można spotkać się z opinią, że pomimo odległości geograficznej najlepszą bazą porównawczą do analizy pewnych zjawisk społecznych zachodzących w Europie Środkowej i Wschodniej jest Izrael. Pojawianie się takich twierdzeń wynika z tego, że korzenie znacznej części populacji dzisiejszego państwa żydowskiego znajdują się właśnie w tej części Starego Kontynentu, a także z powodu charakteru prawnego tego państwa. Zarówno w warstwie formalnej, jak i społecznej, która konstytuuje dzisiejszą wspólnotę polityczną Izraela, można dostrzec silne wpływy środkowoeuropejskiej myśli społecznej, politycznej i prawnej przełomu XIX i XX wieku

* Artykuł napisany w ramach projektu finansowanego przez Narodowe Centrum Nauki (SONATA 12) „Doświadczenie i wspólnota sensu. Estetyczne podstawy walidacji we współczesnej filozofii prawa”, 2016/23/D/HS5/01826.

Prace Kulturoznawcze 24, 2020, nr 1

(C) for this edition by CNS 
oraz pierwszej połowy XX stulecia ${ }^{1}$. O ile takie opinie, formułowane zwłaszcza w dyskursie publicznym, narażone są na liczne uproszczenia, o tyle w wypadku podejmowanej przeze mnie w niniejszym tekście tematyki, czyli myśli Avishaia Margalita odnoszącej się do koncepcji przyzwoitego społeczeństwa i etyki pamięci, wydają się przydatne dla zagadnienia aplikowalności tych koncepcji filozoficznych. Pytanie: „Czy możliwe jest powstanie przyzwoitego społeczeństwa opartego na pamięci zbiorowej, mającej wewnętrzną etykę, w takim interesującym miejscu do badań społecznych, jaki stanowi Europa Środkowa i Wschodnia?” jest w tym wypadku uzasadnione. Odpowiedzi na takie pytania (o możliwość przeniesienia koncepcji Margalita na grunt tej części Europy, w której społeczeństwo wielokulturowe jest znacznie bardziej rozwinięte) szukała już Christina Kleiser. Badaczka w swoim tekście na temat relewantności koncepcji izraelskiego filozofa z zachodnioeuropejskim modelem społecznym podała w wątpliwość tezę, że doświadczenie II wojny światowej i narodowosocjalistycznych zbrodni, konstytuujące dla powojennych wspólnot politycznych w Niemczech i Austrii, jest podzielane przez ich współobywateli, którzy przybyli z Bliskiego Wschodu czy też byłej Jugosławii ${ }^{2}$. Wydaje się jednak, że w kontekście Europy Środkowej i Wschodniej problem aplikowalności nie wynika ze zjawiska multikulturalizmu danego społeczeństwa. Wprost przeciwnie - wynika on zarówno z zasadniczego sporu toczącego się w naszej części Europy, a dotyczącego charakteru i struktury wspólnot politycznych powstałych po upadku komunizmu, kwestii rozliczeń przeszłości, jak i zbieżności elementów konstytuujących wspólnoty. Jednym z kluczowych elementów użytych do uzasadnienia zmian zachodzących w regionie była właśnie pamięć zbiorowa. Odwołania do przeszłości (w formie narracji pamięci) obecnie obowiązujących $\mathrm{w}$ regionie liberalnych i illiberalnych konstytucji (czyli takich, które poprzez rozwiązania prawne w nich zastosowane „odstają” od norm liberalnych demokracji), ale także wcześniejszych aktów prawnych stymulujących procesy konstytuujące utwierdzają mnie w przekonaniu o doniosłym znaczeniu tego konkretnego fenomenu społecznego dla procesów transformacji demokratycznej i późniejszych prób sformułowania nowego modelu społeczno-prawnego. Dotychczasowe analizy tego problemu badawczego skupiały się raczej na rekonstrukcji schematów kształtowania się społecznej pamięci zbiorowej, jak również na analizie konkretnych przypadków narracji pamięci i ich użycia. W polskim oraz środkowoeuropejskim dyskursie naukowym, zwłaszcza w naukach społecznych, wciąż główną rolę odgrywa strona „techniczna”. Dotychczas trudno było jednak

${ }^{1}$ Zob. J. Frankel, Prophecy and Politics. Socialism, Nationalism and the Russian Jews, 1862 1917, Cambridge 2003; A. Shapira, Land and Power. The Zionist Retort to Force, 1881-1948, przeł. W. Templer, Stanford 1999.

2 Zob.C.Kleiser,Avishai Margalit's Idea of anEthicsofMemoryandItsRelevanceforaPluralisticEurope, https:/www.iwm.at/publications/5-junior-visiting-fellows-conferences/vol-xxv/avishai-margalitsidea-of-an-ethics-of-memory/?fbclid=IwAR092rzJlggP6c4M3dvJO4F1XIBiiYk8-DaZSQNfU9OP3a5JvPTB4KFY8ik (dostęp: 10.01.2020). 
odnaleźć pogłębioną analizę dotyczącą społecznych konsekwencji zastosowania takich narracji pamięci i odwołań do przeszłości. Z podobnych brakiem można się spotkać w wypadku „korzystania” z pamięci zbiorowej przez instytucje państwa w celu osiągnięcia konkretnego, zamierzonego celu. Na tym tle rozważania Margalita dotyczące przyzwoitego społeczeństwa ${ }^{3}$ oraz etyki pamięci ${ }^{4}$ mają tym większą wartość. $\mathrm{Z}$ tego również powodu chciałbym zmierzyć się z tą tematyką, nawet pomimo ostrzeżeń, które autor zawarł w podsumowaniu Przyzwoitego spoteczeństwa. Wspomniał on wówczas, że oferowane przez niego kategorie nie są teorią, lecz „raczej opowieścią na temat przyzwoitego społeczeństwa — opowieścią, której bohaterami są pojęcia"5. Ponadto zauważył, że

w pojęciach zawierających się w tej książce kryje się pewne niebezpieczeństwo. Zostały one pozbawione retorycznego dążenia do uwznioślania, które cechuje dyskurs moralny i polityczny. Pobudzające oddziaływanie pojęć, takich jak honor czy upokorzenie, może spowodować, że dyskusja na temat przyzwoitego społeczeństwa zmieni się w czczą gadaninę, dyskusję, która nie dba o prawdę, a jedynie o stworzenie ciepłej, podniosłej atmosfery ${ }^{6}$.

W niniejszym tekście chciałbym omówić (w części pierwszej) dotychczasowe podejścia badawcze do roli społecznej pamięci zbiorowej w procesach społecznych, politycznych i prawnych (ze szczególną uwagą poświęconą prawnym narzędziom państwowej polityki pamięci po upadku komunizmu). W części drugiej i trzeciej omówione zostaną (szczególnie użyteczne dla studiów nad rolą społecznej pamięci zbiorowej w środkowoeuropejskich procesach przejścia demokratycznego i konstytuowania nowych wspólnot politycznych) elementy koncepcji przyzwoitego społeczeństwa, a także rozważania Margalita nad etyką pamięci w omówionym powyżej kontekście. Wnioski poświęcone zostaną z kolei identyfikacji obszarów, w których filozoficzne koncepcje Margalita mogłyby mieć zastosowanie zarówno w zakresie badań nad wspomnianym zjawiskiem społecznym, jak i w sferze praktycznej.

\section{1. Środkowoeuropejska prawnoinstytucjonalna polityka pamięci}

Europejscy badacze, w tym M. Halbwachs, który w pracy Spoleczne ramy pamięci $i^{7}$ sfomułował jako pierwszy koncepcję pamięci zbiorowej, podejmując tę tematykę, skupiali się przede wszystkim na metodach wytwarzania i petryfikowania pamięci. Uwagę skupiali oni przede wszystkim na mechanizmach państwowego

${ }^{3}$ Zob. A. Margalit, The Decent Society, przeł. N. Goldblum, Cambridge MA-London 1998.

${ }^{4}$ Zob. A. Margalit, The Ethics of Memory, Cambridge MA-London 2004.

5 A. Margalit, The Decent..., s. 289. Tłum. N. Goldblum.

${ }^{6}$ Ibidem, s. 289-290.

7 Zob. M. Halbwachs, Społeczne ramy pamięci, przeł. M. Król, Warszawa 1969. 
oddziaływania na pamięć. Zarówno E. Hobsbawm, jak i P. Connerton czy B. Anderson przyjmowali perspektywę badawczą atrakcyjną dla prawnika czy też socjologa prawa, ale zarazem wprowadzającą bardzo jasne rozgraniczenia pomiędzy państwem — jako instytucjonalną całością — a społeczeństwem, ograniczonym tylko do roli odbiorcy komunikatu pamięci. Polska socjolożka B. Misztal w swojej pracy The Theories of Social Remembering określiła jedną z perspektyw badawczych tę skupiającą się na aktywnej roli państwa — mianem podejścia prezentystycznego, rozumianego jako „wynajdywanie tradycji”8.

Ważnym elementem Halbwachsowskiej wizji pamięci zbiorowej jest jej kontekstowość, a w konsekwencji prezentystyczny charakter, polegający na tym, że interpretacja i ocena wydarzeń zawartych w reprodukowanych wspomnieniach indywidualnych są zależne między innymi od posiadanej wiedzy na temat ich konsekwencji. Innymi słowy jednostki wspominające są bogatsze o wiedzę, co stało się pomiędzy momentem, w którym wspomnienie zaistniało, a czasem, gdy dochodzi do reprodukcji wspomnień. W konsekwencji pamięć zbiorowa danej społeczności nie jest wolna od prezentyzmu, jest on jej trwałym i nieodzownym elementem, co wynika z tego, że według Halbwachsa pamięć jest pochodną istnienia tożsamości zbiorowej, a nie odwrotnie. To ukształtowana tożsamość zbiorowości ma determinować formowanie społecznej pamięci. Niemniej jednak wytworzona pamięć zbiorowa przekłada się także na teraźniejszość. Jak zauważył P. Connerton: „rozważając pamięć jako taką, możemy zauważyć, że nasze doświadczenie teraźniejszości w znacznym stopniu zależy od naszej wiedzy o przeszłości. Doświadczamy naszego teraźniejszego świata w kontekście, który jest przyczynowo związany z przeszłymi wydarzeniami i przedmiotami" .

Perspektywa badawcza „wynalazców tradycji” charakteryzuje się przede wszystkim przyjęciem perspektywy Halbwachsa, jednak jak podkreśliła B. Misztal — „nie może być ona [Halbwachsowska wizja pamięci — F.C.] redukowana do wąskiego podejścia prezentystycznego" ${ }^{10}$. W niniejszym tekście jest ona jednak kluczowa dla zrozumienia zarówno perspektywy dotychczasowych badań nad społecznym współpamiętaniem w Europie Środkowej i Wschodniej, jak i identyfikacji mechanizmów jej kształtowania stosowanych w ramach państwowych polityk pamięci na omawianym obszarze. Jak zauważyła bowiem Misztal — autorzy „egzemplifikują w swoich pracach »wynajdywanie« publicznych rytuałów jako jednego z trybów kontroli społecznej"11.

W tak zakreślonej perspektywie studiów nad pamięcią, począwszy od E. Hobsbawma, poprzez P. Connertona, do B. Andersona, rysuje się obraz omnipotentnego państwa, które w ramach takich działań, jak publiczne szkolnictwo,

\footnotetext{
${ }^{8}$ B. Misztal, Theories of Social Remembering, Philadelphia 2003, s. 56.

9 P. Connerton, Jak społeczeństwa pamiętaja, przeł. M. Napiórkowski, Warszawa 2012, s. 33.

${ }^{10}$ B. Misztal, op. cit., s. 55.

11 Ibidem, s. 56.
} 
publiczne obchody upamiętniające czy też lokowanie przekazów pamięci w przestrzeni publicznej (miejsca upamiętnienia) nieustannie oddziałuje na społeczeństwo poprzez transmisję kreowanych przez siebie wizji przeszłości, a w konsekwencji nieustannie wpływa na kierunki kształtowania się pamięci zbiorowej „swojego" społeczeństwa. E. Hobsbawm w pracy Wiek imperium powiązał fakt instytucjonalnej wszechobecności państwa z polityką nacjonalizmu drugiej połowy XIX i pierwszych lat XX wieku. W jego opinii

państwo [wówczas - F.C.] nie tylko tworzyło naród, ale m u s i a ł o [wyr. - F.C.] go tworzyć. Na własnym terytorium rządy mogły na co dzień docierać do każdego obywatela dzięki swym skromnym, lecz wszechobecnym przedstawicielom — od listonoszy i policjantów po nauczycieli oraz (w wielu krajach) pracowników kolei ${ }^{12}$.

Transmisja narracji pamięci miałaby się więc odbywać w sposób kompleksowy: czy to poprzez przekazywane w szkole treści, czy też poprzez nawiązania do historii i wydarzeń z przeszłości w innych dziedzinach życia, na przykład poprzez wzory umundurowania licznych „acz skromnych” przedstawicieli państwa. O ile E. Hobsbawm skupiał się na diagnozie i opisie polityki nacjonalizmu tamtego okresu, którą w innej ze swoich prac nazwał „masową produkcją mitów”"13, o tyle obrzędom upamiętnienia prowadzącym do kształtowania się wspólnoty pamięci większą uwagę poświęcił przywoływany już P. Connerton. Jako studium przypadku posłużyła mu Trzecia Rzesza pomiędzy przejęciem władzy przez NSDAP w 1933 roku a wybuchem II wojny światowej. Ceremoniał świąt państwowych i partyjnych (zrównanych w swoim zasięgu i doniosłości) był uporządkowany i totalny. Connerton nazwał go „rokiem liturgicznym” "14 , nawiązując w ten sposób do niezmiennego charakteru (co do zasady) kalendarza świąt religijnych. Ważne dla niniejszych rozważań są zarówno jego spostrzeżenia na tematu sposobu i semireligijnego charakteru obchodzenia kolejnych rocznic związanych z dochodzeniem NSDAP do władzy, jak i analiza wydarzeń w momencie, w którym dominująca rola NSDAP była już ugruntowana w niemieckim społeczeństwie, a opowieści o historii państwowej i partyjnej zostały połączone w jedną narrację. Znakomicie ukazał on skalę możliwości, jakie ma państwo w kształtowaniu pożądanej przez siebie pamięci zbiorowej, gdy dochodzi do zaniku prawnych i społecznych mechanizmów kontrolnych wynikających chociażby z mechanizmów działania systemów demokratycznych.

Transmisji narracji pamięci przez państwowe instytucje kultury przyjrzał się z kolei B. Anderson. W swoich badaniach zależności pomiędzy byłymi koloniami a oddziałującymi na nie imperiami analizował nie tylko takie zjawiska jak rasizm

12 E. Hobsbawm, Wiek imperium 1875-1914, przeł. M. Starnawski, Warszawa 2015, s. 230.

${ }^{13}$ Zob. E. Hobsbawm, Masowa produkcja tradycji: Europa, lata 1870-1914, [w:] Tradycja wynaleziona, red. E. Hobsbawm, T. Rangers, przeł. M. Godyń, F. Godyń, Kraków 2014.

${ }^{14}$ P. Connerton, op. cit., s. 94. 
i nacjonalizm, ale przyjrzał się także aplikowalności mechanizmów kształtowania polityk pamięci przez kraje, które w ramach dekolonizacji uzyskały pełną niezależność.

W poprawionym wydaniu Wspólnot wyobrażonych ${ }^{15}$ Anderson zauważył , że „od końca osiemnastego wieku nacjonalizm przeszedł proces adaptacji i modulacji względem różnych epok, reżimów politycznych, ekonomicznych i struktur społecznych"16. Omówione przez niego schematy działania poszczególnych państw postkolonialnych znakomicie wykazały zarówno uniwersalny charakter samej polityki nacjonalizmu, jak i pełną aplikowalność metod i narzędzi niezbędnych do transmisji narracji pamięci, a w konsekwencji do wytworzenia pamięci zbiorowych, w których zawarte zostało uzasadnienie istnienia nowopowstałych „tradycji”.

Przekładając omówione koncepcje na środkowoeuropejską praktykę instytucjonalną po upadku komunizmu, należy podkreślić, że (pomimo znacznej zmiany charakteru państw zarówno na poziomie rozwiązań politycznych, ekonomicznych, jak i społecznych) narracje pamięci stały się jedną z istotniejszych zmiennych uzasadniających odrzucenie systemu realnego socjalizmu i potrzebę ustanowienia nowych, liberalno-demokratycznych wspólnot politycznych. Wyrazem takich działań było ulokowanie odwołań do przeszłości w nowych konstytucjach sankcjonujących procesy przejścia demokratycznego i ostatecznie konstytuujących nowe wspólnoty polityczne w Europie Środkowej i Wschodniej.

Już na etapie uchwalania wspomnianych aktów konstytucyjnych odwołania do przeszłości znalazły się w konstytucjach $\mathrm{Czech}^{17}$, Słowacji ${ }^{18}$, Litwy ${ }^{19}$, Estonii ${ }^{20}$,

15 Zob. B. Anderson, Imagined Communities. Reflections on the Origin and Spread of Nationalism, London-New York 2006.

${ }^{16}$ Ibidem, s. 157.

17 Autorzy czeskiej konstytucji z 1992 roku w treści preambuły stwierdzili, że są „wierni dobrym tradycjom dawnej państwowości ziem Korony Czeskiej i państwowości czechosłowackiej”, Konstytucja Republiki Czeskiej, przeł. M. Kruk, Warszawa 1994, http://libr.sejm.gov.pl/tek01/txt/ konst/czechy-a.html (dostęp: 10.01.2020).

18 W konstytucji słowackiej z 1992 roku próżno szukać nawiązań do tradycji wspólnego państwa Czechów i Słowaków. Jej autorzy nawiązali z kolei do tradycji Państwa Wielkomorawskiego i „cyrylo-metodyjskiego dziedzictwa duchowego", Konstytucja Republiki Stowackiej, przeł. K. Skotnicki, Warszawa 2003, http://libr.sejm.gov.p1/tek01/txt/konst/slowacja.html (dostęp: 10.01.2020).

${ }^{19}$ W konstytucji litewskiej opowieść dotyczy narodu Litwinów, który tworzył swoją państwowość w oparciu o statuty litewskie i konstytucje Republiki Litewskiej, bronił swojej niepodległości, ducha narodowego, języka i zwyczajów, a także dążył do odzyskania przyrodzonego prawa, jakim jest życie w niepodległym państwie, Konstytucja Republiki Litewskiej, przeł. H. Wisner, Warszawa 2006.

${ }^{20}$ Autorzy konstytucji Estonii odwołali się do prawa do samostanowienia narodów, którego efektem było powstanie pierwszej Republiki Estońskiej w 1918 roku, Konstytucja Republiki Estońskiej przyjęta przez obywateli Republiki Estońskiej w referendum przeprowadzonym $w$ dniu 28 czerwca 1992 r., przeł. A. Puu, [w:] Konstytucje państw Unii Europejskiej, Warszawa 2011. 
Polski $^{21}$. Natomiast konstytucje Rumunii ${ }^{22}$ i Łotwy ${ }^{23}$ zostały o nie uzupełnione w XXI wieku. Stało się tak również na Węgrzech, jednak tutaj zastosowano je dopiero w illiberalnej konstytucji, czyli Ustawie zasadniczej z 2011 roku $^{24}$ uchwalonej przez obóz polityczny V. Orbana. Z wyjątkiem Rumunii w każdym z wymienionych przypadków odniesienia do przeszłości ulokowane zostały w szczególnej części aktu konstytucyjnego - w preambule. Jej szczególny charakter wynika z roli, jaką odgrywa ona w treści aktów prawnych. J. Přibáň, za N. Luhmannem, w swojej pracy Legal Symbolism stwierdził, że w preambułach „samoobligująca wola suwerennego ludu zostaje uroczyście skodyfikowana oraz przekształcona w moralne, mityczne fundamenty społeczności politycznej”"25. Z kolei A. Młynarska-Sobaczewska zauważyła, że jej rolą jest „wyjaśnienie celu [w jakim został

${ }^{21} \mathrm{~W}$ preambule do polskiej konstytucji z 1997 roku występują nawiązania między innymi do „najlepszych tradycji Pierwszej i Drugiej Rzeczypospolitej” i do okresu „gdy podstawowe wartości i prawa człowieka były w naszej Ojczyźnie łamane”, Konstytucja Rzeczypospolitej Polskiej, Dz.U. z 1997 r. Nr 78, poz. 483 z późn. zm.

${ }^{22}$ Konstytucja Rumunii nie jest wyposażona w preambułę. Narracje pamięci, a właściwie narracja została ulokowana w tekście właściwym, a dokładnie w art. 1 ust. 3. W 2003 roku doszło do jego przeredagowania przez dodanie do jego treści następujących słów „w duchu demokratycznych tradycji narodu Rumuńskiego i ideałów rewolucji grudnia 1989 roku". Od tej pory Rumunia jest demokratycznym i społecznym państwem prawa, w którym godność człowieka, prawa i wolności obywatelskie, swobodny rozwój osobowości ludzkiej, sprawiedliwość oraz pluralizm polityczny są wartościami najwyższymi, „w duchu demokratycznych tradycji narodu Rumuńskiego i ideałów rewolucji grudnia 1989 roku i są gwarantowane", Constitution of Romania, http://www.cdep.ro/pls/ dic/site.page?id=371 (dostęp: 4.10.2019).

${ }^{23}$ Do 2014 roku konstytucja Łotwy nie zawierała preambuły. Motywy odtworzenia państwa po upadku ZSRR były zawarte w Deklaracji niepodległości uchwalonej przez Radę Najwyższą Łotewskiej Socjalistycznej Republiki Radzieckiej. Zawierała ona liczne narracje pamięci, a także dokładny opis naruszeń praworządności, które doprowadziły najpierw do sfałszowanych wyborów, a następnie włączenia tego państwa do ZSRR (zob. 4. maijs, Rakstu, atminu un dokumentu krajums per Neatkaribas deklaracju, red. T. Jundza, Riga 2000, s. 356). Wydarzeniem, które spowodowało uzupełnienie konstytucji Łotwy o preambułę, było przegrane przez mniejszość rosyjską tak zwane referendum językowe, w którym jej przedstawiciele domagali się reformy konstytucyjnej i uznania języka rosyjskiego za równorzędny urzędowy język Łotwy. W konsekwencji w 2014 roku uchwalono poprawkę do konstytucji Łotwy, dodając do niej preambułę zawierającą odwołania do przeszłości i narracje pamięci, zob. Constitution of Latvia, https://likumi.lv/ta/en/id/57980-the-constitution-of-the-republic-of-latvia (dostęp: 7.10.2019).

${ }^{24}$ Omówienie wszystkich odwołań i narracji pamięci zawartych w preambule do konstytucji Węgier wymaga odrębnego artykułu. Niemniej podkreślić należy jej etniczny i illiberalny charakter zarówno na poziomie treści, jak i zastosowanej w niej semantyki. Ustawa zasadnicza Węgier nie jest nazwana literalnie „konstytucją”. To słowo nie pada tam ani razu. Podobnie jak w wypadku nazwy państwa - Węgry - nie występują żadne przedrostki o republikańskim charakterze państwa. Wreszcie preambuła nosi nazwę „Narodowego wyznania wiary”, co sugeruje, że dopiero bezwarunkowe uznanie zawartych w niej treści spowoduje pełnoprawną przynależność do wspólnoty, zob. Ustawa zasadnicza Wegier, przeł. J. Snopek, Warszawa 2012.

25 J. Přibáň, Legal Symbolizm, On Law, Time and European Identity, Aldershot 2007, s. 5.

Prace Kulturoznawcze 24, 2020, nr 1

(C) for this edition by CNS 
uchwalony - F.C.] i wskazanie podstaw aksjologicznych"26. Sam fakt zastosowania odwołań do przeszłości w treści aktów konstytucyjnych autorka uzasadniła dążeniem przez prawodawcę do „uzyskania przekonania o prawowitości działania twórców konstytucji i następnie władz działających na jej podstawie"27.

Uczynienie z przeszłości jednego w najważniejszych elementów demokratycznej wspólnoty politycznej miał następnie przełożenie na politykę instytucji państwowych. Przywoływany już J. Přibáň zauważył, że narracje pamięci zawarte w preambule do polskiej konstytucji stanowią ,interesujące połączenie obywatelskiego i narodowego patriotyzmu"28. Wydaje się jednak, że zdanie to definiuje procesy społecznoprawne zachodzące w ostatnich latach w całej Europie Środkowej i Wschodniej. Politykę instytucjonalną na polu pamięci rozumiem między innymi jako dążenie państw regionu do dalszego kontrolowania treści pamięci zbiorowych swoich społeczeństw, a także wpływanie na procesy ich kształtowania, na przykład przez tworzenie wyspecjalizowanych instytucji, takich jak instytuty pamięci narodowej powstające w wielu krajach Europy Środkowo-Wschodniej ${ }^{29}$.

Podsumowując pokrótce dotychczasowe rozważania, należy podkreślić, że o ile wspomniane przykłady badań nad społeczną pamięcią zbiorową, a także relacje pomiędzy społecznym współpamiętaniem a jego użytecznością w okresie formowania wspólnot politycznych po upadku komunizmu w Europie Środkowej i Wschodniej dostarczają ciekawego materiału empirycznego, o tyle wyraźnie widać, że brakuje w nich głębszej refleksji zarówno filozoficznej, jak i dotyczącej etyki społecznej. Przywołani autorzy w znakomity sposób zrekonstruowali schematy kształtowania i państwowego oddziaływania na pamięć. Jednocześnie ograniczyli się tylko do takich działań. Nie podjęli się, z czego nie można czynić znacznego zarzutu, oceny możliwości adaptacyjnych danych społeczności do warunków tworzonych przez politykę (w tym politykę prawną) państwa rozumianego jako instytucjonalna całość. Tę właśnie lukę we wspomnianych obszarach badań nad społecznym współpamiętaniem, a także rolą pamięci w procesach kompleksowych przemian politycznych mogłyby wypełnić kategorie oferowane przez filozofię A. Margalita.

\section{Etyczna pamięć zbiorowa przyzwoitego środkowoeuropejskiego społeczeństwa}

Konstruowanie przez rządzących narracji pamięci (których przykłady przytoczyłem w poprzednim podrozdziale) tak, aby uzasadniały one prawomocność da-

${ }^{26}$ A. Młynarska-Sobaczewska, Normatywizacja tożsamości zbiorowej w preambułach do konstytucji państw postkomunistycznych, „Filozofia Publiczna i Edukacja Demokratyczna” 2, 2013, nr 2, s. 109.

27 Ibidem, s. 111.

28 J. Přibáň, op. cit., s. 85.

${ }^{29}$ Instytucje o takim profilu istnieją także między innymi w Czechach, Rumunii, Bułgarii, na Węgrzech, Słowacji, Ukrainie i na Litwie.

Prace Kulturoznawcze 24, 2020, nr 1

(C) for this edition by CNS 
nych rządów, było jedynie częścią większego procesu zmian. Problemy społeczne i prawne, z jakimi musiały — i wciąż muszą — mierzyć się społeczeństwa żyjące w czasach transformacji ustrojowej, dotyczą de facto każdego z elementów życia społecznego. Procesy nazwane przez C. Thornhilla „trzecią falą konstytucji”30, czyli środkowoeuropejska transformacja demokratyczna, miały najbardziej kompleksowy charakter z wszystkich powojennych transformacji demokratycznych. W konsekwencji transformacji musiały ulec wszystkie (w przeciwieństwie do dwóch poprzednich europejskich „fal konstytucji”) dziedziny życia społecznego, a nie tylko obszar polityczno-ustrojowy. Dlatego też elementy rozważań A. Margalita zawarte w obu wskazanych już jego pracach chciałbym odnieść do zjawisk charakterystycznych dla omawianego okresu, to jest budowy: społeczeństwa pluralistycznego i demokratycznego funkcjonującego w ramach wolnorynkowego systemu gospodarczego; społeczeństwa funkcjonującego w systemie politycznym zawierającym wymienione elementy, a także gwarantującego ochronę praw indywidualnych i skupionego na tej ochronie; społeczeństw żyjących we wspólnotach politycznych, nie tylko powstałych w ramach obietnicy lepszej przyszłości (co jest charakterystyczne dla środkowoeuropejskiej transformacji), lecz także mocno zakotwiczonych w przeszłości i czerpiących z niej legitymizację. W wypadku ostatniego elementu nie bez znaczenia pozostają mechanizmy rozliczeń przeszłości, a także ramy czasowe ich działania.

Margalit konstruował swoją koncepcję przyzwoitego społeczeństwa przede wszystkim jako wspólnotę wolną od dążenia do upokorzenia swoich członków, upokarzania dokonywanego w każdy sposób i na każdym polu — zarówno ekonomicznym, jak i politycznym. Rozpoczynając swoje rozważania od pojęć prawa, honoru i upokorzenia, przechodzi do konkretnych elementów działania społeczeństwa i instytucjonalnego funkcjonowania współczesnego państwa (co sam nazwał „poddaniem testowi instytucji społecznych”31), pokazując tym samym możliwość adaptacji swoich przemyśleń do konkretnych przypadków. W niniejszym tekście chciałbym się skupić na tych elementach, które mogą być lub nawet zostały już w pewien sposób przez środkowoeuropejskie (i nie tylko) ośrodki władzy powiązane z problematyką społecznego współpamiętania, to jest na kategoriach biurokracji, społeczeństwa opiekuńczego, a także na rozważaniach na temat kary w przyzwoitym społeczeństwie.

Społeczeństwo opiekuńcze analizowane było przez Margalita, podobnie jak biurokracja, z bardzo konkretnej perspektywy - relacji ekonomicznych i ich wpływu na kształtowanie się przyzwoitego społeczeństwa. Samym zaś źródłem tego konkretnego typu społeczeństwa jest odrzucenie elementów filantropii, zarówno symbolicznych, jak i psychologicznych, które prowadzą do upokorzenia słabszego uczestnika interakcji społecznych. Niemniej, jak Margalit sam zauważył, model państwa opiekuńczego nie wyklucza ewentualnego upokorzenia, które

${ }^{30}$ Zob. C. Thornhill, A Sociology of Constitutions. Constitutions and State Legitimacy in Historical-Sociological Perspective, Cambridge 2011, s. 355.

31 Zob. A. Margalit, The Decent..., s. 187. 
w tym wypadku może być przeniesione na poziom instytucjonalny, a czynnikiem upokarzającym staje się stworzona do obsługi państwa opiekuńczego bezosobowa machina biurokratyczna. Samo znalezienie się w niedostatku powoduje u danej osoby dyskomfort, który może wzmacniać poczucie upokorzenia.

Jakie przełożenie ma kwestia dyskomfortu wynikającego z niedostatku ekonomicznego na kwestie dotyczące pamięci? W mojej opinii dyskomfort wynikający ze zmniejszenia się zasobów może dotyczyć nie tylko kwestii materialnych, lecz także psychologicznych i tożsamościowych. Innymi słowy współzależność występująca pomiędzy biurokracją, państwem i społeczeństwem opiekuńczym, a także przyzwoitym społeczeństwem ma przełożenie na inne niż ekonomiczne sfery życia. W wypadku odgórnie prowadzonej polityki pamięci kluczem jest sposób reakcji ogółu na niedostatek (jeszcze raz podkreślę — nie tylko dóbr materialnych, lecz na przykład kultury, z którą dana osoba się utożsamia) jako sytuację upokarzającą. Reorientacja państwowej polityki pamięci może $\mathrm{w}$ konsekwencji prowadzić (i z reguły prowadzi) do wykluczenia z nowo powstałego (a głównego) nurtu części członków społeczeństwa, którzy do tej pory w nim funkcjonowali. W konsekwencji wykluczeni zaczynają wytracać swój dotychczasowy kapitał kulturowy, który gwarantował im odpowiednią pozycję w poprzedniej formacji społecznej.

W kontekście omawianej polityki państw w okresie transformacji zjawisko to może występować w dwojaki sposób: po pierwsze, bezpośredni — wówczas wykluczenie poza główny nurt może wynikać z dążenia do odpłaty za czyny popełnione w trakcie trwania systemu niedemokratycznego (które w danym okresie mogły być legalne lub przynajmniej politycznie akceptowalne i argumentowane bieżącym interesem systemu politycznego); po drugie zaś, w sposób pośredni poprzez stymulowaną systemowo ewolucję narracji głównego nurtu prowadzącą do przemian kulturowych. W obu wypadkach doniosłą rolę odgrywają narzędzia prawne.

Postulaty ukarania przestępstw (w tym społeczne dążenie do ukarania sprawców czynów motywowanych politycznie) popełnionych w okresie niedemokratycznym, a także rozliczenie zinstytucjonalizowanej przemocy państwowej wobec niezgadzających się z ideologicznymi ramami funkcjonowania społeczeństwa, wyznaczonymi przez reżim, należy traktować jako naturalne. Tego typu postulaty przez dłuższy czas przeważały w dyskursie publicznym w ramach tematyki rozliczeń z przeszłością. Nie da się również zaprzeczyć, że nierealizowanie tych postulatów, ich częściowa, długotrwała lub nieefektywna realizacja były argumentem w rękach kontestatorów przemian zarówno w Polsce, jak i w całym omawianym regionie. Charakter i sposób ukarania sprawców omawianych przestępstw był i wciąż jest przedmiotem wielu dyskusji. W nurcie socjologii prawa istnieje bogata literatura dotycząca tak zwanej sprawiedliwości okresu przejściowego (nazywanej też sprawiedliwością tranzycyjną). To właśnie jej charakter ${ }^{32}$, a także

32 Znacznie bliższe jest mi stanowisko R. Teitel, która uważa sprawiedliwość tranzycyjną za koncepcję typową jedynie dla okresu przeobrażeń politycznych, taką też perspektywę przyjmuję w niniejszym artykule, zob. eadem, Transitional Justice, Oxford 2000. 
płynne ramy czasowe działania jej mechanizmów powodują najwięcej konfliktów wewnątrz społeczeństw wychodzących z traumy systemów niedemokratycznych. Wynikają one w dużej mierze $\mathrm{z}$ właściwości opisywanego rodzaju sprawiedliwości: selektywności, kontekstowości i transformacyjnego charakteru ${ }^{33}$. W każdym $\mathrm{z}$ wymienionych wypadków omawiany model sprawiedliwości ma zastosowanie wyłącznie w sytuacji spełnienia określonych warunków. Problematyczna jest jednak płynność ich granic. Dochodzi więc do skrajnej indywidualizacji rozważań nad przynależnością danego przypadku do sprawiedliwości tranzycyjnej, a to z kolei może stymulować poczucie niesprawiedliwości zarówno jednostek, jak i zbiorowości. Stosując język Margalita, należy podkreślić, że mogą one się poczuć upokorzone tym, że konkretne zdarzenie - w ich pamięci indywidualnej czy też zbiorowej noszące znamiona czegoś doniosłego — zostaje pominięte przez czynnik decyzyjny (na przykład biurokrację) jako mało znaczące.

Kara i polityka karna według Margalita przede wszystkim nie mogą upokarzać. Takie stanowisko jest naturalną konsekwencją analiz wszystkich wcześniejszych zmiennych. Niezależnie od czynu w przyzwoitym społeczeństwie sprawca wciąż pozostaje człowiekiem.

Otwartą kwestią jest natomiast usunięcie elementu upokorzenia $\mathrm{z}$ samego procesu wykonania kary. Autor nie miał wątpliwości co do tego, jak przyzwoite społeczeństwo powinno się zachowywać wobec więźniów - ma ich nie upokarzać. Abstrahując od sporów teoretycznych na temat społecznej i indywidualnej funkcji stosowania kar, należy zastanowić się nad teorią Margalita właśnie w kontekście rozliczeń z systemami niedemokratycznymi. Jak wiadomo, do momentu przełomu w Europie Środkowej i Wschodniej, jak również w czasie trwania przemian wykształciły się dwa systemy kolektywnego radzenia sobie z traumami przeszłości. Pierwszym z nich była tak zwana zbiorowa amnezja zastosowana na Półwyspie Iberyjskim. Drugim było instytucjonalne dążenie do pojednania poprzez oczyszczenie polegające na wyznaniu win przed organem quasi-sądowym, który przebaczał sprawcy w imieniu ofiar, jednocześnie legitymizując swoją decyzję autorytetem nowo powstałej demokratycznej wspólnoty politycznej. Innymi słowy mowa tu o modelu znanym na przykład z Republiki Południowej Afryki specjalnej komisji prawdy i pojednania. W obu wypadkach wartości humanitarne i uniwersalne miały wziąć górę nad żądzą prostego rewanżu na dotychczasowych oprawcach. Żaden reżim i żadne popierające go społeczeństwo nie spełniają warunków funkcjonowania jako przyzwoite społeczeństwo. Nawet jeśli realizowały one kryteria ekonomiczne nieupokarzania, to zawsze pogrążał je system represji.

Europa Środkowa i Wschodnia nie skorzystały z opisanych modeli radzenia sobie z przeszłością. Wypracowały własny, wspomniany na początku niniejszego tekstu, który możemy nazwać państwowym oddziaływaniem na pamięć poprzez wyspecjalizowane instytucje i instytuty. Jednak w okresie, w którym mogłyby być zastosowane mechanizmy sprawiedliwości okresu przejściowego (sprawied-

33 Zob. M. Krotoszyński, Modele sprawiedliwości tranzycyjnej, Poznań 2017, s. 170. 
liwości tranzycyjnej), takie instytucje jeszcze nie funkcjonowały. Elementem symbolicznego napiętnowania miało być w tym wypadku ujawnienie współpracy $z$ upadłym reżimem niedemokratycznym, czyli lustracja. Przybrała ona różne formy w zależności od państwa: od restrykcyjnej w Czechach, poprzez łączącą w sobie elementy ukrytego pojednania i ukarania (w Polsce negatywne konsekwencje swojego oświadczenia ponosi tylko kłamca lustracyjny), po niestosowanie jakiejkolwiek masowej lustracji przy jednoczesnym odgórnym określeniu ram czasowych, do których należało zerwać z reżimem bez żadnych późniejszych konsekwencji. Przykładowo: jeśli podmiot prawa po wyznaczonej dacie nadal działa w strukturach reżimowych, poniesie konsekwencje ${ }^{34}$. Niemniej kwestia ukarania za przestępstwa polityczne nadal budzi kontrowersje, podobnie jak lustracja. Wydaje się, że zastosowanie tu Margalitowskiej wizji kary, która nie upokarza nawet tych, którzy upokarzali, z jednej strony jest w pełni uzasadnione, ponieważ pozwala na ocenę konkretnych działań organów demokratycznego państwa w stosunku do tych, którzy w imię ideologii naruszali prawa podstawowe i prawa człowieka. Jednocześnie jednak, podobnie jak w wypadku sprawiedliwości tranzycyjnej, nie oferuje ona jasnych kryteriów podziału i zastosowania. W konsekwencji nie rozwiązuje ona najbardziej palących problemów dotyczących tej tematyki.

O ile zagadnienia powiązane $\mathrm{z}$ działaniami polegającymi bezpośrednio na ukaraniu bądź odstąpieniu od karania osób zaangażowanych w system niedemokratyczny są łatwe do przeanalizowania i opisania, o tyle działania pośrednie stanowią znacznie bardziej rozmytą kategorię. Kapitał kulturowy w społeczeństwach niedemokratycznych bardzo często oparty jest na strukturach nieformalnych, pewnego rodzaju „,brudnej wspólnocie” ${ }^{35}$, której wiele ze swoich prac poświęcił A. Podgórecki. Zgodnie z jego założeniami utrata wpływu na instytucje publiczne, które brudna wspólnota wykorzystuje do celów prywatnych, musi oznaczać utratę części posiadanego kapitału kulturowego. Margalit zarówno w omawianym Przyzwoitym społeczeństwie, jak i w innym tekście (napisanym wspólnie z M. Halbertalem) ${ }^{36}$ podjął problem znaczenia kultury, która ma „nie upokarzać

${ }^{34}$ Przykładem takiego rozwiązania jest prawo wyborcze Łotwy. Osoby, które pozostawały w strukturach Łotewskiej SRR lub federalnych ZSRR po 13 stycznia 1991 roku, wskutek nowelizacji konstytucji z 1998 roku utraciły bierne prawo wyborcze. Do dziś wraca co jakiś czas sprawa łotewskiej eurodeputowanej Tatiany Żdanoki, która domaga się wykreślenia tego przepisu z konstytucji. W orzeczeniu z 2006 roku Europejski Trybunał Praw Człowieka oddalił jej skargę (zob. Żdanoka v. Latvia, 58278/00, https://hudoc.echr.coe.int/eng\#\{\%22itemid\%22:[\%22001-72794\%22]) i stwierdził, że łotewski odpowiednik PKW miał prawo skreślić ją z listy kandydatów do parlamentu, jako że po wskazanej dacie pozostawała członkinią powiązanego z Komunistyczną Partią Związku Radzieckiego Interfrontu, jawnie dążącego do storpedowania wyjścia Łotwy ze struktur ZSRR.

35 Zob. A. Podgórecki, Kontrola społeczna trzeciego stopnia, [w:] Elementy socjologii prawa, t. 3, red. A. Kojder et al., Warszawa 1990, s. 78-84.

${ }^{36}$ Zob. M. Halbertal, A. Margalit, Liberalism and the right to culture, „Social Research” 61, 1994, nr 3, s. 491-510. 
znajdujących się w jej orbicie" ${ }^{37}$. Postulowany przez nich model kultury powinien być inny od kultury państw i społeczeństw, w których pełni ona funkcję służebną wobec polityki. Jak zauważył Margalit — „kultura przyzwoitego społeczeństwa nie wymaga »socjalistycznego realizmu«, w którym »siły postępu« i najsłabsze grupy są portretowane w jak najlepszym świetle" ${ }^{38}$. Same zaś wytwory kultury nie powinny być przyczyną sytuacji, w której ktokolwiek z odbiorców funkcjonujących w przyzwoitym społeczeństwie mógłby się poczuć upokorzony. Jak już wspominałem, kulturowy element państwowej polityki pamięci, wzmocniony dodatkowo obwarowaniami prawnymi (na polskim gruncie znakomitym przykładem jest tak zwana ustawa dekomunizacyjna ${ }^{39}$ ), prowadzi do stopniowej, ewolucyjnej przebudowy społecznej pamięci zbiorowej. Poprzez uznanie pewnych treści za nieprzystające do narracji głównego nurtu, na przykład z mocy prawa, ruguje się je z obszarów, w których w jakikolwiek sposób mogłyby one oddziaływać na społeczną świadomość (może to być przestrzeń publiczna czy też na przykład lista obowiązkowych lektur szkolnych). W konsekwencji członkowie społeczeństwa utożsamiający się z odrzuconymi narracjami i budujący wokół nich swoje systemy odniesienia zostają odgórnie kulturowo zubożeni. Naturalnie kwestią odrębnych rozważań powinno być uzasadnienie dla takich działań jak rugowanie narracji i tradycji antydemokratycznych z przestrzeni publicznej, niemniej faktem jest, że takie działania nie odpowiadają Margalitowemu postulatowi kultury niekrępującej wrażliwości odbiorcy.

Wszystkie pozostałe omówione elementy mają doniosłe zastosowanie zarówno na poziomie państwowej polityki pamięci, jak i w wypadku wynikających z niej działań instytucjonalnych. Z punktu widzenia socjologa prawa oprócz omówionej problematyki kary w okresie transformacji demokratycznej również pozostałe zmienne Margalitowego przyzwoitego społeczeństwa mogą mieć tu zastosowanie. Ciekawym przykładem kwestii związanych z kulturowym aspektem współpamiętania może być tu inicjatywa niepochodząca co prawda $\mathrm{z}$ omawianego obszaru, jednak wpisująca się swoją logiką w pewien trend dotyczący działań na polu pamięci społecznej. Inicjatywa ta polega na działaniach, które są argumentowane między innymi takimi kategoriami jak prawo do wiedzy, szczęścia itp., a które mogą być również utożsamiane z Margalitowym dążeniem do „nieupokarzania” jednostek w społeczeństwie. Jest to inicjatywa autonomicznego parlamentu Kraju Basków dotycząca ustanowienia „Instytutu Pamięci, Współistnienia i Praw Człowieka"40.

37 A. Margalit, The Decent..., s. 162.

${ }^{38}$ Ibidem, s. 163.

39 Zob. ustawa o zakazie propagowania komunizmu lub innego ustroju totalitarnego przez nazwy jednostek organizacyjnych, jednostek pomocniczych gminy, budowli, obiektów i urządzeń użyteczności publicznej oraz pomniki, Dz.U. z 2016 r. poz. 744 z późn. zm.

40 Zob. Ley 4/2014, de 27 de noviembre, de creación del Instituto de la Memoria, la Convivencia y los Derechos Humanos, https://www.boe.es/eli/es-pv/1/2014/11/27/4 (dostęp: 10.10.2019). 
Dążenie do politycznego oddziaływania na pole społecznej pamięci zbiorowej przypisywane jest raczej Europie Środkowej i Wschodniej. Jak jednak pokazuje poniższy przykład, omawiane schematy i kategorie mają w sobie pewien potencjał uniwersalny. Mogą one być zastosowane pod jednym warunkiem, a mianowicie gdy spełniony jest wymóg, że oddziałują one albo na grupę o homogenicznym charakterze (w tym wypadku Basków), albo też w ramach większej zbiorowości pojawia się dążenie do konsolidacji i promocji kultury dominującej. Wówczas obie omawiane kategorie Margalita mają nie tylko zastosowanie, ale wręcz ich charakterystyka służyć może sformułowaniu zmiennych niezbędnych do oceny poszczególnych działań na polu polityki.

Swoją decyzję o powołaniu instytutu deputowani wspólnoty autonomicznej uzasadnili między innymi tym, że pamięć jest prawem obywatelskim, nie zaś obowiązkiem. Z kolei dostęp do wiedzy o naruszeniach wartości demokratycznych i praw człowieka jest naturalną konsekwencją tego prawa. Sama pamięć zdaniem autorów ustawy jest konstrukcją „,wielościenną", konfliktową i dynamiczną, ponieważ reprodukowane wspomnienia „są częścią tego, co zapamiętane, ale u każdej osoby są subiektywnie skonfigurowane"41. Dlatego też społeczeństwo potrzebuje profesjonalnej instytucji, która dostarczy mu niezbędnej wiedzy. Prawodawca jednej z hiszpańskich wspólnot autonomicznych uznał więc prawo do pamiętania za jedno z praw podstawowych i przyrodzonych. Cały dalszy wywód autonomicznego ustawodawcy zawarty w motywach uchwalenia aktu, uzasadniający powstanie Instytutu Pamięci, Współistnienia i Praw Człowieka, jest pokłosiem tego twierdzenia. W treści aktu powołującego baskijski instytut ujawniają się także wszystkie omówione dotychczas elementy rozważań Margalita. Po pierwsze, polityczny byt instytucjonalny mający uprawnienia do działania na polu pamięci (baskijska autonomia), którego członkowie mają świadomość indywidualnego charakteru pamięci autobiograficznej - i wyraźnie to podkreślają w uzasadnieniu ustawy - bierze odpowiedzialność za odpowiednie sformatowanie narracji pamięci. Ponadto jego członkowie są również świadomi jej niedostatków i ewentualnego destrukcyjnego wpływu na społeczeństwo. Dlatego też podejmują działania administracyjne mające doprowadzić do chociaż częściowej unifikacji pamięci. W konsekwencji aparat urzędniczy wspólnoty autonomicznej stwierdza, że tylko on jest zdolny do „zaopiekowania” się pamięcią swojej społeczności, ponieważ ma ku temu narzędzia (prawo). W efekcie będzie więc dążył do maksymalnej uniwersalizacji narracji pamięci funkcjonujących w społeczeństwie baskijskim. Indywidualne traumy staną się częścią większej opowieści. Ostatecznie ich indywidualna moc wynikająca $\mathrm{z}$ emocjonalnej opowieści osoby nazywanej świadkiem historii zostanie osłabiona.

Odrzucenie opowieści indywidualnej na rzecz stworzenia uniwersalnej opowieści o przeszłości sformatowanej przez ośrodek władzy politycznej jest pod-

${ }^{41}$ Ibidem. 
stawą i zarazem najbardziej problematycznym elementem omawianego podejścia do pamięci zbiorowej, czyli podejścia „wynalazców tradycji”. Działania baskijskiego, autonomicznego prawodawcy podyktowane są również presją kulturową, w której kultura wspólnoty ma zostać umocniona poprzez dostarczenie jej odpowiednich treści (narracji) wzmacniających argumentację o konieczności budowy pamięci zbiorowej tej wspólnoty.

Jak już podnosiłem, dotychczasowe europejskie badania nad zjawiskiem kształtowania społecznej pamięci zbiorowej poprzez państwowe „wynajdowanie tradycji" skupiały się — z pewnymi wyjątkami — przede wszystkim na stronie technicznej omawianych procesów. Procesy te zostały dogłębnie przeanalizowane, omówione, opisane i zrekonstruowane, zresztą z definicji sformułowanych przez europejskich badaczy korzysta też Margalit, stwierdzając, że „,pamięć zbiorowa ma swoich przedstawicieli i przedstawicielki, którym powierzono jej zachowanie i szerzenie" ${ }^{42}$. Niemniej Margalitowa perspektywa pamięci i etyki współpamiętania jest inna od wizji „wynalazców tradycji”. Dlatego też może posłużyć jako źródło refleksji nad takimi kwestiami, jak chociażby stan poszczególnych społecznych pamięci zbiorowych wytworzonych wskutek działania mechanizmów państwowych polityk pamięci. Dotychczas instrumenty te traktowane były jako fakt, skuteczny mechanizm oddziaływania na społeczeństwo, prowadzący do ukonstytuowania się wspólnoty, zarówno wielkiej (na przykład politycznej, kształtowanej na podstawie narracji zawartych w konstytucjach), jak i mniejszych grup czy też mniejszości (Baskowie). Niemniej kwestie oceny etycznej działań państwa nie były w nich podnoszone. Etyczny aspekt społecznego współpamiętania, choć na pierwszy rzut oka sprawia wrażenie raczej postulatu aniżeli skonkretyzowanej kategorii badawczej, może wprowadzić elementy podtrzymujące ducha społeczeństwa pluralistycznego zarówno do debaty nad treściami znajdującymi się w szeregu narracji pamięci, jak i do samej legislacji dotyczącej tego elementu życia społecznego.

Łącznik sformułowany przez Margalita pomiędzy etyką i moralnością, nawet jeśli etyka pamięci ma dotyczyć relacji znacznie bliższych, osobistych niż interakcje zachodzące $w$ ramach przyzwoitego społeczeństwa, ma również fundamentalne znaczenie dla oceny polityk pamięci we współczesnych społeczeństwach. Przenosząc z kolei kwestie pamiętania na poziom metafizyczny, poprzez stwierdzenie „»życie w czyichś opowieściach « jest tylko wymyślną metaforą w szarej rzeczywistości, w której ludzie mogą mówić o nas i wspominać nas po naszej śmierci. Nie ma w tym niczego tajemniczego w tym typie egzystencji, w porównaniu z innymi formami życia po życiu"43, potwierdza on jedynie słuszność poglądów o sztucznym charakterze zjawiska, które Connerton określił „metafizyczną współczesnością”. To właśnie wspomniany element „sztuczności” jest przyczyną, dla

\footnotetext{
42 A. Margalit, The Ethics..., s. 147.

43 Ibidem, s. 92.
} 
której użycie kategorii etycznych w ocenie działań czynnika państwowego może być korzystne dla dotychczas prowadzonych badań. Zresztą Margalit w swoich rozważaniach użył bardzo dobrego przykładu — roli Kosowa dla państwowości Serbów. Obraz ten jest utrwalony w serbskiej pamięci zbiorowej. Z jednej strony filozof wskazał na uwypukloną w tym obrazie doniosłość klęski rycerzy serbskich na Kosowym Polu dla późniejszych losów tej zbiorowości, z drugiej zaś wskazał, jak pamięć o nich została instrumentalnie potraktowana przez Slobodana Miloševicia w trakcie konfliktu w 1999 roku.

Ciekawe wydaje się również pytanie o oczekiwania jednostek wobec pamięci zbiorowej: Czy jednostka w ogóle może oczekiwać bycia zapamiętaną? Margalit zasadnie podkreślił, że nie powinniśmy oczekiwać od wspólnoty bycia zapamiętanym. Podobnie jak słusznie zauważył, że etyczne pamiętanie, a właściwie powiedziałbym współpamiętanie, może prowadzić do oczyszczenia relacji pomiędzy członkami wspólnoty pamięci. Współuczestnicy procesów formujących społeczną pamięć zbiorową poprzez ocenę poszczególnych zdarzeń mogą przecież dokonywać takiej selekcji narracji pamięci, która pozwoli na zwiększenie inkluzywności proponowanych narracji. Innymi słowy zastosowanie kryteriów etycznych w dyskursie pamięci w teorii powinno pozwolić na wydobycie z przeszłości tego, co łączy, a nie dzieli. Stąd już tylko krok do przyzwoitego społeczeństwa, którego pamięć nie prowadzi do upokorzenia któregokolwiek z jego członków.

3. Wnioski

D. Gawin stwierdził (odwołując się do Weberowskich zasad legitymizacji), że nowoczesne - kapitalistyczne i demokratyczne społeczeństwa miały czerpać prawomocność swojego systemu władzy politycznej ze sfery prawnoinstytucjonalnej. W tym podziale wyraźnemu rozgraniczeniu uległy sfery pamięci i władzy — przeszłość i pamięć o niej były źródłem legalności władzy w tradycyjnych społeczeństwach, w których wszelkie działania, struktury oraz instytucje uprawomocniono poprzez odwołanie się do odwiecznych zasad i reguł. Odwiecznych to znaczy takich, których historyczne korzenie giną w mrokach przeszłości i mogą być zapośredniczone tylko poprzez mity, symbole oraz wierzenia ${ }^{44}$.

Europa Środkowa i Wschodnia w okresie transformacji daleka była od czerpania swojej legitymizacji ze sfery instytucji. To właśnie historyczne korzenie były uzasadnieniem powstania nowych organizmów politycznych na gruzach byłych sowieckich satelitów czy też republik związkowych. Proponowane przez A. Margalita kategorie wiele wnoszą do badań i debaty nad instytucjonalną polityką na polu pamięci stosowaną przez państwa znajdujące się w omawianej części świata. Wynika to $\mathrm{z}$ faktu, że pamięć zbiorowa była i jest traktowana w naszym regio-

${ }^{44}$ D. Gawin, Legitymizacja i pamięć, [w:] Legitymizacja w Polsce. Nieustający kryzys w zmieniających się warunkach?, red. A. Rychard, H. Domański, Warszawa 2010, s. 17. 
nie przez czynnik polityczny w sposób stricte instrumentalny. Prowadzone na ten temat badania społeczne i prawne, a także ich kierunek są pokłosiem decyzji podejmowanych przez wyznaczających trendy - polityków. Wyłomem w takiej perspektywie badawczej jest praca L. Koczanowicza Polityka czasu ${ }^{45}$, w której autor zmierzył się z problemem politycznego aspektu upływu czasu. Książka ta miała charakter zdecydowanie bardziej koncepcyjny aniżeli rekonstrukcyjny.

Sposób i intencja stosowania przez rządzących narzędzi prawnych w celu wzmocnienia swojego przekazu i zarazem petryfikacji transmitowanych do społeczeństwa narracji pamięci tylko potwierdzają odmienny charakter pracy L. Koczanowicza. Można odnieść wrażenie, że współcześni środkowoeuropejscy „wynalazcy tradycji” pomimo zachodzących wokół nich zmian społecznych nadal traktują kwestie społecznego współpamiętania jako zjawisko całkowicie wewnątrzpaństwowe, które podobnie jak w XIX i na początku XX wieku można dowolnie kształtować. Być może zbyt jaskrawym, ale ze względu na swoją plastyczność dobrym będzie jeden z epizodów z Roku 1984 Orwella, gdy główny bohater odpowiedzialny za „oczyszczanie” państwowego przekazu ze sprzeczności, jakie wynikły ze zmiany opinii Wielkiego Brata, po prostu odnajduje w prasie wypowiedzi wodza niespójne z aktualnym, oficjalnym przekazem, wycina je i wrzuca do specjalnej tuby, która transportuje je do wielkiego pieca. W tym wypadku państwo doprowadza do sytuacji, w której niepożądane treści znikają na zawsze z jakichkolwiek źródeł. Jak już wspomniałem, przykład ten jest w odniesieniu do współczesności przejaskrawiony, ale już słynne „poprawienie” zdjęcia Stalina w latach trzydziestych — wymazanie Nikołaja Jeżowa — jest faktem. Oba przykłady — zarówno literacki, jak i historyczny — powinny uzmysłowić nam schematy działania władzy na polu pamięci, ujawniają zrekonstruowane w literaturze przedmiotu i przedstawione w tym tekście metody działania rządzących w obszarze pamięci zbiorowej.

Dzieje się tak pomimo generalnej zmiany modelu społeczno-politycznego, o której wspominał D. Gawin, a z którą mamy do czynienia w Europie Środkowej i Wschodniej. Stoję na stanowisku, że jest to rodzaj niezamierzonego eksperymentu, który, jak zauważył J. Přibáň, jest połączeniem obywatelskiego i etnicznego patriotyzmu. Innymi słowy jest to próba połączenia elementów komunitarnych z liberalnymi, a używając trochę innych pojęć - liberalnej demokracji z państwem narodowym. Margalit i Halbertal w przywoływanym już artykule Liberalism and the right to culture stwierdzili: „,wnioskujemy, że państwa, szczególnie państwa narodowe, muszą być neutralne w stosunku do kultury większości, z jednoczesnym jej poszanowaniem, a także powinny wspierać kultury mniejszości posiadające specjalne przywileje" 46 . Pewną paradoksalność tego wniosku rozwi-

45 Zob. L. Koczanowicz, Polityka czasu. Dynamika tożsamości w postkomunistycznej Polsce, przeł. K. Liszka, Wrocław 2009.

${ }^{46}$ M. Halbertal, A. Margalit, op. cit., s. 510. 
kłali poprzez stwierdzenie, że już sam charakter dominującej kultury pozwala na jej kształtowanie poprzez interakcje społeczne. Innymi słowy nie grozi jej rozpłynięcie się w innej kulturze. Z kolei ,przywileje [należałoby - F.C.] zagwarantować mniejszościom w celu ich ochrony [...], aby ewentualne pozostawienie tych kwestii wolnemu rynkowi nie doprowadziło do opanowania całej sfery publicznej przez kulturę dominującą"47.

Innymi słowy według autorów to właśnie na państwie narodowym spoczywa szczególny ciężar dążenia do zachowania neutralności, ponieważ skala działania kultury dominującej, nawet bez dodatkowego państwowego wspomagania, może prowadzić do likwidacji kultur mniejszości. Z kolei omawiane w niniejszym tekście polityki pamięci z Europy Środkowej i Wschodniej zdają się dążyć do dominacji. Dążenia takie są wpisane w historię regionu, a twórcy wspólnot politycznych powstałych na gruzach komunizmu nie zauważają zmiany kontekstu społecznego, politycznego i prawnego, jaka nastąpiła po 1989 roku.

W zaproponowanych przez Margalita kategoriach etycznego pamiętania i przyzwoitego społeczeństwa dostrzegam spory potencjał dla badaczy, a także rządzących. Należy przy tym pamiętać, że potencjał ten możliwy jest do realizacji tylko w pewnych formacjach społecznych, w których współuczestnicy procesów — na przykład współpamiętania - operują taką samą lub przynajmniej zbliżoną siatką pojęciową. Jak słusznie zauważyła przywoływana już C. Kleiser - w wypadku społeczeństw o dużej różnorodności szansa jego zastosowania może budzić pewne wątpliwości. Kategorie sformułowane przez A. Margalita mogą poprzez swój wydźwięk doprowadzić do redukcji napięć zachodzących w ramach takich konfliktów wartości, jak pamięć indywidualna-pamięć zbiorowa, pamięć mniejszości-oficjalna pamięć państwowa czy też do redukcji napięć pomiędzy jednostkami dążącymi do wyegzekwowania swoich uprawnień indywidualnych a interesem większej zbiorowości. Oczywiście, jak zauważył Margalit, są to raczej propozycje aniżeli jasno sprecyzowane kategorie, jednak ze względu na charakter podejmowanej problematyki może to być wyłącznie ich zaletą. Zarówno w kontekście pamiętania o przeszłości, jak i jej rozliczania konieczne jest bowiem zachowanie kontekstu, w jakim dane zdarzenie zaistniało. Nie bez znaczenia jest tu podniesiona we wstępie kwestia wspólnoty doświadczeń (mimo odległości dzielącej osoby, które jej doznawały). Margalit formułował swoje koncepcje nie tylko w środowisku częściowo wywodzącym się z omawianego regionu Europy Środkowej i Wschodniej, lecz także funkcjonującym w ramach pamięci o doświadczeniu, jakim była II wojna światowa. Ponadto myśl ta osadzona jest w społeczeństwie funkcjonującym w ramach liberalnego systemu politycznego wzmocnionego przekazem typowym dla państwa narodowego. Szukanie więc analogii pomiędzy Europą Środkową i Wschodnią, a Izraelem ma uzasadnienie

${ }^{47}$ Ibidem. 
pod warunkiem spełnienia warunku monokulturowości lub przynajmniej funkcjonowania na danym obszarze dominującej kultury pamięci.

Czy zatem możliwe jest stworzenie przyzwoitego społeczeństwa opartego na etycznej pamięci? Na to pytanie nie da się odpowiedzieć wprost. Omawiane kategorie są dobrym kierunkiem, który może stymulować dążenie do powstania takiej formuły społeczeństwa. Ponadto mogą one posłużyć jako zmienne służące do oceny jakości prawodawstwa dotyczącego państwowych polityk pamięci. Wówczas możliwe stanie się sformułowanie narzędzi kontrolujących możliwość upokorzenia poszczególnych jednostek na skutek działań podjętych przez władzę. Etyczny charakter pamięci jako rodzaju zobowiązania stanowiłby z kolei przeciwwagę dla aspektu technicznego — narzędzi oceny. Dlatego też uważam, że pomimo ostrzeżeń samego autora warto zmierzyć się z formułowanymi przez niego postulatami.

\section{Struggles with memory. Central Eastern Europe and Avishai Margalit's concepts of decent society and ethics of memory}

\section{Abstract}

The main goal of the paper is an identification and presentation of Margalit's philosophical categories' potential for their application in CEE socio-legal studies on collective memories and the constitutionalization of the political communities after 1989. Both "decent society" and the "ethics of memory" are an added value for the recent discussion on that problem. That is the reason why their comparison with the actual state of knowledge and the reality of societal collective memories' petrification by several political factors is crucial. Looking for an answer to the question formulated in the article's title will help in the identification of the fields which could be enriched by Margalit's philosophy.

Keywords: politics of memory, constitutionalization, collective memory, decent society, ethics of memory, democratic transition, CEE

\section{Bibliografia}

4. maijs, Rakstu, atminu un dokumentu krajums per Neatkaribas deklaracju, red. T. Jundza, Riga 2000.

Anderson B., Imagined Communities. Reflections on the Origin and Spread of Nationalism (revised edition), London-New York 2006.

Connerton P., Jak społeczeństwa pamiętają, przeł. M. Napiórkowski, Warszawa 2012.

Frankel J., Prophecy and Politics. Socialism, Nationalism and the Russian Jews, 1862-1917, Cambridge 2003.

Gawin D., Legitymizacja i pamięć, [w:] Legitymizacja w Polsce. Nieustajacy kryzys w zmieniajacych się warunkach?, red. A. Rychard, H. Domański, Warszawa 2010. 
Halbwachs M., Społeczne ramy pamięci, przeł. M. Król, Warszawa 1969.

Halbertal M., Margalit A., Liberalism and the right to culture, „Social Research” 61, 1994, nr 3, s. $491-510$.

Hobsbawm E., Masowa produkcja tradycji: Europa, lata 1870-1914, [w:] Tradycja wynaleziona, red. E. Hobsbawm, T. Rangers, przeł. M. Godyń, F. Godyń, Kraków 2014.

Hobsbawm E., Wiek imperium 1875-1914, przeł. M. Starnawski, Warszawa 2015.

Kleiser C., Avishai Margalit's Idea of an Ethics of Memory and Its Relevance for a Pluralistic Europe, https://www.iwm.at/publications/5-junior-visiting-fellows-conferences/vol-xxv/avishai-margalits-idea-of-an-ethics-of-memory/?fbclid=IwAR092rzJlggP6c4M3dvJO4F1X1BiiYk8-DaZSQNfU9OP3a5JvPTB4KFY8ik.

Koczanowicz L., Polityka czasu. Dynamika tożsamości w postkomunistycznej Polsce, przeł. K. Liszka, Wrocław 2009.

Krotoszyński M., Modele sprawiedliwości tranzycyjnej, Poznań 2017.

Margalit A., The Decent Society, przeł. N. Goldblum, Cambridge MA-London 1996.

Margalit A., The Ethics of Memory, Cambridge MA-London 2004.

Misztal B., Theories of Social Remembering, Philadelphia 2003.

Młynarska-Sobaczewska A., Normatywizacja tożsamości zbiorowej w preambułach do konstytucji państw postkomunistycznych, „Filozofia Publiczna i Edukacja Demokratyczna” 2, 2013.

Podgórecki A., Kontrola społeczna trzeciego stopnia, [w:] Elementy socjologii prawa, t. 3, red. A. Kojder et al., Warszawa 1990.

Přibáň J., Legal Symbolizm. On Law, Time and European Identity, Aldershot 2007.

Shapira A., Land and Power. The Zionist Retort to Force, 1881-1948, przeł. W. Templer, Stanford 1999.

Teitel R., Transitional Justice, Oxford 2000.

Thornhill C., A Sociology of Constitutions. Constitutions and State Legitimacy in HistoricalSociological Perspective, Cambridge 2011.

Filip Cyuńczyk — doktor nauk prawnych, absolwent Międzynarodowego Instytutu Socjologii Prawa w Onati (Uniwersytet Kraju Basków), badacz stowarzyszony w Centrum Edukacji Prawniczej i Teorii Społecznej (CLEST) Uniwersytetu Wrocławskiego, wykładowca wizytujący w Riga Graduate School of Law. Doktorat uzyskał, broniąc pracy doktorskiej pt. Narodowe instytuty pamięci i ich miejsce w społecznej i prawnej rzeczywistości państw postkomunistycznych w Europie Środkowej $i$ Wschodniej.

filip.cyunczyk@gmail.com 